\title{
Management of Business Risk Hedging in Construction Contracts from the Perspective of Public Investors
}

\author{
Barbara Andrlova, Jana Korytarova*
}

\begin{abstract}
Risk management of construction projects presented in the article focuses on the management of business risk from the perspective of public investors in public works contracts in the Czech Republic. Based on the data analysis and a comparative study of specific attributes in contracts for works, the result of the research has been a portfolio of specific instruments and their recommended parameters for effective business risk management. Qualitative analysis was conducted using a questionnaire survey and structured interviews with public sector representatives to share their views on the current practice of protecting public procurement with regard to mitigate business risk. Types, functions and recommended parameters of hedging instruments has been proposed. Effective forms of hedging are mainly liability insurance for damage to things, property and health, contractual penalties, retention money and bank guarantees. Results of the research were compared with foreign practice and international contractual standards.
\end{abstract}

Keywords: business risk management; construction project; contract for work; hedging instrument; public works contract; retention money

\section{INTRODUCTION}

Priority of the business environment in every developed country shall be economic stability of companies and providing safe and healthy competitive environment. Public procurement for construction works contracts forms a significant part of construction production in the Czech Republic. Current developments in the construction industry state: "The production of civil engineering, which is mainly dependent on public funding, annually grew by 4.0\%." [1] Preparation and implementation of construction contracts brings a number of risks that may endanger the achievement of the objectives of construction projects. Therefore, it is in the interest of all stakeholders to minimize the probability of risks occurrence and to reduce the intensity of their impact.

The interaction between construction, insurance and the law stems from the activity generated by the construction process [2]. MultiStakeholder Consultative Framework for Construction Health and Safety presents the role of client and project manager and importance of their relationship [3]. Conscious acceptance of investment risks and risk allocation based on the ability to control them by the project participants is therefore a necessary precondition for achieving success in a public construction project.

The aim of this research is to gain insight into the issue of business risk management in contracts for work in construction projects. Contract risk is defined as a risk or set of risks that has the capacity to impact on a contract to the extent that it deviates from the outcome expected by either party [4]. To protect investor, contractor and other shareholder interests, all of them need to be proactive in assessing their contract risks. By taking a proactive approach to contracts, companies help mitigate contractual risks while making improvements that will enhance the business through increasing revenues or reducing costs [5]. According to [6], effective risk management typically generates positive results on a project by improving the project performance, increasing the cost-effectiveness and creating a good working relationship between contracting parties.

The intention is to verify whether the forms of hedging used and their parameters specified in the contracts are effective in practice, i.e. if they fulfil their function, and whether the choice of a suitable hedging instrument affects business risk management of the project or whether the appropriate combination of hedging instruments increases the effectiveness of the construction contracts protection. For this purpose, quantitative research and data analysis were performed on a comparative study. The findings were completed by a qualitative survey carried out among the representatives of the public sector. Comments by foreign experts in the field of construction and engineering law are also provided.

\section{RESEARCH METHODOLOGY}

Based on a scientific literature research about hedging in construction projects $[7,8]$, a quantitative research into the forms of hedging used in contracts for work in practice was proposed. Furthermore, a qualitative survey was carried out using the method of structured questionnaires and interviews with representatives of public investors in order to share their views on the issue. A comparison of the forms of hedging used on an international scale was also made.

\subsection{Quantitative Research}

The research set consisted of a database of selected public works contracts defined by the field of activity according to the CPV (Common Procurement Vocabulary) code list and codes 45000000-7 - Construction work and 45200000-9 - Works for complete or part construction and civil engineering work. The contract agreements were published in the phase of performance of contracts for work on the profiles of contracting authorities during the 20112018 period. As part of the analysis, a structured database of input values was created according to the tender documentation. As part of quantitative research, a comparative study of case studies of a selected category of civil engineering works construction was designed on the construction and reconstruction of public buildings research set, for which the public investor is responsible for financing. 
Partial parts of the research were processed in successive steps (see Fig. 1).

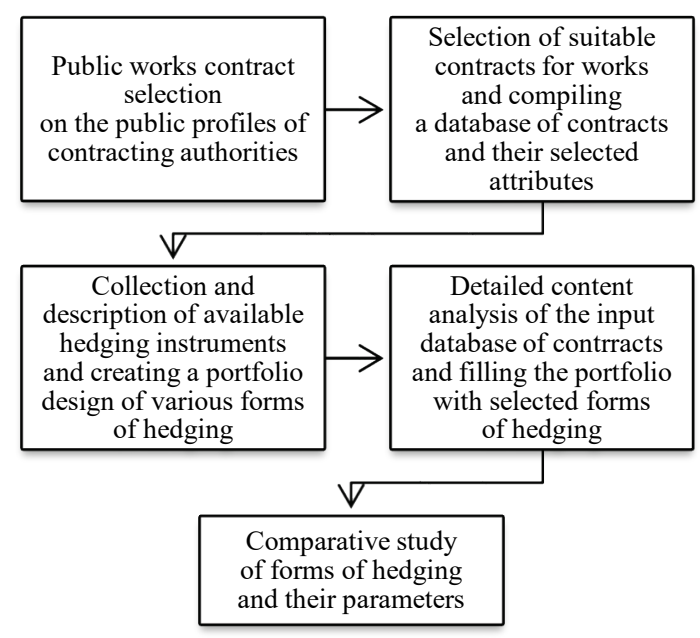

Figure 1 Methodology and procedure of quantitative research Source: authors' own processing

Contracts for work and their amendments, i.e. publicly available documents and related information provided in procurement procedures at the stage of publishing of the final contract for work, were subject to detailed content analysis. The research set consisted of 66 contracts for work in total. The resulting conditional selection filter included two research samples - case studies:

- $\quad 35$ contract agreements for construction work projects related to the building modifications of school buildings in the 2011-2016 period [9],

- 31 contract agreements for construction work projects related to the construction of homes for the elderly in the 2013-2018 period [10].

For the purpose of systematic data processing, an item structure of 28 selected attributes from the calls of public procurement was created for the input database of available forms of hedging and their parameters in real work contracts in practice, which were subsequently researched. Defined forms of hedging according to the draft of the standards of the General Terms and Conditions [11] were also used for the creation of available hedging forms database. A total of 1,675 input values were obtained from the content analysis, from which a final database of the used hedging forms and their parameters was created in the text and numerical formats in the research set of work contracts. The conclusions of the case studies research were complemented by construction work projects in the field of wastewater treatment [12] and were summarized in a comparative study, which were used to create a portfolio of effective forms of hedging, as shown in the research results.

\subsection{Qualitative Research}

The aim of the qualitative research was to supplement the performed data analysis with regard to the used hedging instruments in work contracts and to verify their real use in practice. Qualitative research was carried out using the method of a structured questionnaire and structures interviews. The questionnaire was compiled on the basis of the results of quantitative research and pilot-tested at the investment department of the Regional Office of the South Moravian Region. In June 2019, responsible persons from the ranks of public investors from all regional authorities in the Czech Republic were approached with a request to fill in an online questionnaire and to share their perspective from practice on the issues addressed. Data from the Central Bohemian Region, the Liberec Region, the South Moravian Region and the Capital City of Prague were obtained. To supplement the online questionnaire survey, topics for structures interviews were proposed, which were conducted with the representatives of public investors. Representatives of the regional authorities of the South Moravian and North Moravian regions, who are founders and implement investment plans in their scope (237 contributory organizations in the South Moravian Region, 221 contributory organizations in the Moravian-Silesian Region - hospitals, schools, cultural facilities, roads of class II and III etc.) were approached to share their experience.

\section{RESULTS}

Based on a scientific literature research, quantitative research and data analysis, a qualitative survey using structured questionnaires and interviews with investor representatives, the findings of the researched issue were summarized in a portfolio of effective forms of hedging in work contracts for the construction works. Results of the research were compared with current foreign practice and international contractual standards.

\subsection{Results of Quantitative Research}

Both analysis and data analysis of the research set were performed on a representative data set, which consisted in the creation of a database of contracts for work of sector-specific public procurement for construction work. The content analysis made it possible to find out and describe which sanction arrangements and hedging instruments occur in the contracts for work and with what parameters. The selection of hedging instruments and their amount have been effectively adjusted to protect both parties - the investor and the supplier - throughout the course of the whole construction project. A detailed analysis of the forms of hedging in the research set revealed that the hedging instruments used for risk management were mainly:

- Liability insurance for damage to things, property and health,

- Contractual penalties,

- Retention money,

- Bank guarantees.

The agreed forms of hedging and sanction arrangements are expected to be assigned a contractual consequence and their amount should discourage breach of the contract. From the investor's point of view, it is more efficient to have 
a suitable insurance for the given construction project or to keep a part of the contract price as a retention in case of noncompliance with the supplier's obligations. Common errors in contractual penalty arrangements were identified as vagueness in the specification of obligations, errors in business conditions, confusing indications for the application of contractual penalties or interest on arrears, and disproportionate amounts of penalties.

The resulting comparison of research samples showed that liability insurance for damage to things, property and health increased over time from the original $80-100 \%$ to the insurance of at least in the amount of the contract price up to twice the price of the work. Unreasonable claims can adversely affect the costs associated with acquiring insurance if they do not correspond to the actual or future value of the contract. Retention money rates of $10 \%$ occurred in one third of the cases researched.

The Bank Guarantee for the proper execution of the work (Performance Guarantee) and the Warranty Guarantee gradually replace the application of the retention. An important aspect of the comparative study appeared to be the comparison of case studies with the values of other industryspecific contracts. Therefore, a comparison of the forms of hedging in the field of wastewater treatment [12] was carried out, which states that retention was considered a traditional form of business risk management in contacts for work until 2013, later it tended to be more often replaced by a bank guarantee.

\subsection{Results of Qualitative Research}

The results proved the topicality of the subject and the preventive, sanction and reimbursement functions of hedging instruments were confirmed in practice. To effectively hedge contractual relations, it is necessary to individually set the optimal and effective portfolio of hedging instruments and their parameters for each public procurement, which increases the complexity of preparing the tender documentation and contract documents on the part of public investors and places increased demands on the quality of project documentation.

\subsubsection{Questionnaire Survey}

The aim of the questionnaire survey was to find out the most frequently used hedging instruments and to describe their use effectiveness in contracts for work to hedge business risks from the perspective of a public investor. Answers to the researched issue were obtained from representatives of four regional authorities - from the employees of public procurement departments and from the employees of the investment department.

Respondents agreed that contractual penalties, bank guarantees, retention and work insurance represent effective hedging instruments in the performance of a contractual obligation. Respondents confirmed that the interest of contractors in procurements covered from public funds results from the certainty of financial performance. However, the current situation in public procurement is complicated by the complexity of the procurement process and the lack of interest of contractors in reference contracts. The respondents told: "There is currently lower interest from suppliers - there is not enough labour force."; "To improve the contractual relationship would help perceiving the successful implementation of the contract as a common goal of the investor and the contractor - a relationship based on mutual cooperation, risk management and timely resolution of problems." Public investors see lack of interest on the part of contractors in the risk of negative media coverage (public opinion) in case of non-compliance with the conditions of the project, in the restrictive conditions of subsidy programmes, unfortunate interest of investors only in the cheapest offer, lack of capacity of contractors or subcontractors and the boom in the construction industry. The respondents identified difficulties that are important for the effective performance of the contractual relationship: risks of an administrative and financial character, failure to meet the work schedule and the progress of the construction contract, frequent problems with subcontractors, poor project management of the construction contract and inability to communicate successfully. According to half of the respondents, changes in the project compared to the original proposal are almost always caused by a fault in the project documentation.

\subsubsection{Structured Interviews}

The interviews showed that the hedging instruments are useful, however the price of the work is decisive, otherwise it discourages the contractor from signing the contract. Hedging in work contracts always includes work insurance construction and assembly insurance and liability insurance for damage to things, property and health, contractual penalty agreements, retention and sometimes bank guarantees. Tenderers have the choice of applying for a bank guarantee or a retention, which may be required at $10-20 \%$ of the price of the work. The retention is bound to the successful course of the approval procedure, then it is released. Experience shows that companies do not want a bank guarantee. Defects during the warranty period can be claimed directly by the user of the finished construction work, in addition to the investor. Contractual penalties are agreed for each public procurement by agreement of the contracting parties.

\subsection{International Comparison of Used Forms of Hedging}

Abroad, the usual amount of retention money ranges from $5-10 \%$ of the contract price and there are various procedures for the maturity of the retention. In most American states, retainage (in AmE means retention money) is a typical practice in both public and private construction contracts and permissive nature of retainage varies from state to state. Some owners and prime contractors believe the retainage serves as a type of insurance for owners, but it can have the unfortunate effect for subcontractors to add the hidden cost of retainage to their bid offer which increases the cost to owners. Therefore some states have reduced the maximum rate of retainage permitted. In [13] is shown the Retainage Laws in the 50 States in public sector (highway 
work, projects of municipalities and counties, school buildings etc.). In most states retainage shall not exceed 5\% of the value of the work completed by the contractor. The amount of retainage in California for public works contract payments ranges from $10 \%$ to $5 \%$, in most cases [14].

According to [15], which covers common issues in Construction \& Engineering Laws and Regulations in 32 jurisdictions, the contractual retention in England is usually $3-5 \%$ of contract price. Half of the amount is usually released at practical completion of construction project and the rest after the expiry of the liability period or after issuing a certificate under the contract.

Contractual arrangements for sanctions (contractual penalties) represent a commonly used tool for allocating risks in construction contracts. Bank guarantee for the proper execution of the work (Performance Bond) guarantee that the contractor honours his obligation and duly fulfils the terms of the contract. The guarantee serves to guarantee the date and quality of the delivery for the period between the signing of the contract and the take-over of the finished work. Another bank guarantee is a guarantee for the quality of the work during the warranty period (Warranty Bond) for the period between the take-over and termination of the supplier's liability, i.e. the expiry of the limitation period. The contractual parties can in principle agree on a percentage of guarantees. However, if the bank guarantees are specified in the general terms and conditions of the investor or in the contract, the percentage is limited according to German case law. Performance Bond can reach up to $10 \%$ of the purchase price and Warranty Bond up to $5 \%$. These data became a standard in small and medium-sized projects. However, larger construction projects may be subject to significantly higher values. For example, in Norway, in accordance with [16] the supplier provides the investor with retention for the fulfilment of his contractual obligations during the execution period and the warranty period. Retention money during the implementation phase of the project, including liability for late completion, represents $10 \%$ of the contract price. Upon take-over/delivery of the work, the retention is reduced to $3 \%$ of the contract price for any warranty claims for a period of three years. The retention is provided in the form of a standard bank guarantee (not an on-demand guarantee) from a bank, insurance company or other financial institution. In Sweden, the rules [17] apply, which limit the bank guarantee (Performance Bond) to $10 \%$ of the contract price during the construction implementation until the approval of the final inspection/handover. The warranty in favour of the customer is reduced to $5 \%$ of the contract price during the first two years of the warranty period.

\subsection{Portfolio of Effective Forms of Hedging in Public Works Contracts}

It was confirmed within the research and performed data analysis that effective forms of hedging for risk management are mainly:

- Liability insurance for damage to things, property and health,

- Contractual penalties,
- Retention money,

- Bank guarantees.

The obligation to arrange insurance is included in the qualification criteria of the tender documentation for the public procurement as a fundamental part of the fulfilment of the contractual obligation. Due to the uniqueness of each project, it is appropriate to approach the insurance of each work individually [7].

Retention in the form of a financial retainment primarily serve to ensure the take-over of the construction work by the contracting authority in a completed state without defects and unfinished work and is commonly used by public investors. However, retentions can be large amounts of money and may cause cash flow problems for contractors and the supply chain or in case to recover retention money from the client, perhaps in a situation where the client has incorrectly identified something as a defect [18]. Therefore, its recommended amount is $5 \%$, at max. $10 \%$ of the price of the work. Current practice shows that bank guarantees provide the investor with similar hedging as a retention, but offer suppliers more benefits. Commonly used bank guarantees on the financial market, their functions, parameters and recommended maturity are listed in Tab. 1.

Table 1 Types, functions, parameters and maturity of bank guarantees Sources: authors' own processing; Klee, 2018 [19].

\begin{tabular}{|c|c|c|}
\hline $\begin{array}{c}\text { Type } \\
\text { of bank guarantee }\end{array}$ & $\begin{array}{c}\text { Recommended } \\
\text { parameters }\end{array}$ & Maturity of the bank guarantee \\
\hline Tender Guarantee & $\begin{array}{c}\text { 1-5\% of the } \\
\text { expected value }\end{array}$ & $\begin{array}{c}\text { After the end of the selection } \\
\text { procedure for the contractor }\end{array}$ \\
\hline $\begin{array}{c}\text { Performance } \\
\text { Guarantee }\end{array}$ & $\begin{array}{c}5-10 \% \text { of the } \\
\text { contract price } \\
\text { After completion of the work } \\
\text { the deadline for take-over the } \\
\text { work without defects and } \\
\text { unfinished work + 30 days) }\end{array}$ \\
\hline $\begin{array}{c}\text { Warranty } \\
\text { Guarantee }\end{array}$ & $\begin{array}{c}5-10 \% \text { of the } \\
\text { contract price }\end{array}$ & $\begin{array}{c}\text { After the warranty period } \\
\text { expiration }\end{array}$ \\
\hline $\begin{array}{c}\text { Retention } \\
\text { Guarantee }\end{array}$ & $\begin{array}{c}5-10 \% \text { of the } \\
\text { contract price }\end{array}$ & $\begin{array}{c}\text { Upon completion of a certain phase } \\
\text { of the project, after the deadline for } \\
\text { defect notification }\end{array}$ \\
\hline $\begin{array}{c}\text { Advance } \\
\text { Payment } \\
\text { Guarantee }\end{array}$ & $\begin{array}{c}5-30 \% \text { of the } \\
\text { contract price }\end{array}$ & $\begin{array}{c}\text { After the expected date of } \\
\text { completion of the delivery of } \\
\text { work/service }\end{array}$ \\
\hline
\end{tabular}

Tab. 2 summarizes the basic types of contractual penalties and their parameters according to the general business conditions for the construction completion [11] and provides a comparison with the basic types of contractual penalties and their recommended parameters according to the research results. For some types of penalties, it is proposed to consider reducing the parameters to $0.05 \%$ of the amount owed or to increase the penalty in case of error and to prevent the contractor from non-cooperating in elimination of defects and unfinished work.

The portfolio of effectively selected hedging instruments and their parameters in the work contract for a specific construction project allows the public investor to ensure and meet the material objectives of the public procurement in terms of compliance with the three imperatives - time, cost and work quality and thus help to meet the principle of $3 \mathrm{E}-$ economy, efficiency and effectiveness of investment 
construction project not only in the Czech Republic but also in contract management in the member states of the EU [21].

\begin{tabular}{|c|c|c|}
\hline $\begin{array}{l}\text { Type and } \\
\text { function of the } \\
\text { contractual } \\
\text { penalty }\end{array}$ & $\begin{array}{c}\text { General terms } \\
\text { and conditions for } \\
\text { construction completion } \\
{[11]}\end{array}$ & $\begin{array}{l}\text { Recommended } \\
\text { parameters for } \\
\text { the amount of } \\
\text { contractual penalty } \\
\text { [own work] }\end{array}$ \\
\hline $\begin{array}{c}\text { For late payment } \\
\text { with monetary } \\
\text { performance }\end{array}$ & $\begin{array}{l}0.1 \% \text { of the amount due } \\
\text { for each day of delay }\end{array}$ & $\begin{array}{c}0.05-0.1 \% \\
\text { of the amount due for } \\
\text { each day of delay }\end{array}$ \\
\hline $\begin{array}{c}\text { For failure to } \\
\text { meet the deadline } \\
\text { for completion of } \\
\text { the work }\end{array}$ & $\begin{array}{c}0.1 \% \text { from the price of the } \\
\text { work for each started day } \\
\text { of delay; may not exceed } \\
10 \% \text { of the price of the } \\
\text { work }\end{array}$ & $\begin{array}{l}0.05-0.1 \% \text { from the } \\
\text { price of the work for } \\
\text { each started day of delay }\end{array}$ \\
\hline $\begin{array}{c}\text { For failure to } \\
\text { eliminate defects } \\
\text { and unfinished } \\
\text { work }\end{array}$ & $\begin{array}{c}C Z K 1,000 \text { for each piece } \\
\text { of unfinished work or } \\
\text { defect which is delayed } \\
\text { and for each day of the } \\
\text { delay } \\
\end{array}$ & $\begin{array}{l}C Z K 1,000-5,000 \text { for } \\
\text { each piece of unfinished } \\
\text { work or defect which is } \\
\text { delayed and for each day } \\
\text { of the delay }\end{array}$ \\
\hline $\begin{array}{l}\text { For not clearing } \\
\text { the construction } \\
\text { site }\end{array}$ & $\begin{array}{l}C Z K 5,000 \text { for each day of } \\
\text { the delay }\end{array}$ & $\begin{array}{c}C Z K 1,000-5,000 \text { for } \\
\text { each started day of the } \\
\text { delay }\end{array}$ \\
\hline $\begin{array}{l}\text { For failure to } \\
\text { eliminate the } \\
\text { claimed defects } \\
\text { during the } \\
\text { warranty period }\end{array}$ & $\begin{array}{l}C Z K 1,000 \text { for each defect } \\
\text { which is delayed and for } \\
\text { each day of delay; if it is a } \\
\text { defect that prevents the } \\
\text { proper use of the work, or } \\
\text { if there is a risk of large- } \\
\text { scale damage - an } \\
\text { accident, both parties } \\
\text { agree on a contractual } \\
\text { penalty in the twice } \\
\text { amount }\end{array}$ & $\begin{array}{l}\text { Minimum of } C Z K 1,000 \\
\text { for each defect which is } \\
\text { in delay and for each } \\
\text { day of delay; if it is a } \\
\text { defect that prevents the } \\
\text { proper use of the work, } \\
\text { or if there is a risk of } \\
\text { large-scale damage - an } \\
\text { accident, both parties } \\
\text { agree on contractual } \\
\text { penalties in the twice } \\
\text { amount }\end{array}$ \\
\hline
\end{tabular}

Note: exchange rate EUR/CZK is $27.67,15.05 .2020$

\section{DISCUSSION}

The result of the research is the design of a portfolio of hedging instruments for protection of contractual obligations against business risk so that their function for which they were determined (preventive, sanction or reimbursement) was fulfilled. In a qualitative survey using the method of a questionnaire and structured interviews, it was found out that investors carefully consider the choice of hedging instruments when establishing a contractual relationship with the contractor in order to protect a construction project with respect to business risk management. Optimal composition of hedging instruments increases the efficiency of protection of a specific construction order. It should be noted that there is a portfolio of hedging instruments, the parameters of which are defined by the rules of subsidy programmes, legal norms and decrees, which change over time and according to custom. The contracting authority must take into account the principles of $3 \mathrm{E}$ in any purchasing and management, which should ensure compliance with the scope and quality, fulfilment of objectives and social benefits of the public construction project. The results of the work can increase awareness of conceptual knowledge of technical, economic and legal areas and improve approaches to risk management and contract management throughout the life cycle of a construction project.

The results of this work and foreign experience show that there is no standardized procedure to replace the need for systematic risk identification and risk analysis of each specific construction project. In the preparatory phase, the client's professional ability is to set priorities for each individual construction project on the part of the public investor, which no standardized procedure would replace. The evaluation of tenders by directors of construction companies in the Czech Republic is not perceived very positively (CEEC Research, Q4/2019) and the public sector has significant room for improvement in this respect, e.g. in the responsible procedure in public procurement.

A useful tool for sharing international experience are [21] managed by the Global Legal Group from the UK, is available at https://iclg.com. For the purposes of this research, information from the field of Construction \& Engineering Laws and Regulations was used, which includes key topics occurring in designing and implementation of construction projects, supervision of construction contracts, dispute resolution, etc. Statements of ICLG database professional contributors contained comments on selected forms of hedging - retention, sanction arrangements and bank guarantee in various countries.

The issue of retention money has provoked government review, for example in the United Kingdom, where economic impacts on suppliers due to retained funds are perceived in practice, affecting cash flows of the companies or being completely lost in the event of insolvency in the supply chain. Currently, the Department for Business, Energy \& Industrial Strategy of the Government monitors the costs, benefits and impacts of using retention on the entire construction sector. In 2017, an extensive scientific report on Retentions in the Construction Industry [22] was prepared. The methodology of this report could be an inspiration to map the current situation of this issue in other countries.

\section{CONCLUSION}

The article presents the forms of business risk hedging of the construction work, which should be identified, analysed and managed within the corporate risk management, especially in the pre-investment phase and subsequently incorporated into the contract for work in the investment phase of the construction project. Effective forms of hedging are mainly liability insurance for damage to things, property and health, contractual penalties, retention money and bank guarantees. Types, functions and recommended parameters of hedging instruments has been proposed. The hedging conditions set out in the contracts for work should be proportionate and should provide a balanced allocation of risks and responsibilities between the contracting parties, then the contract will have an capacity to manage business risk mitigation.

The aim of the public investor is to ensure the economic efficiency of investment plans and to protect the investment funds spent from public sources. The agreed conditions in the contracts for work should reflect the objectives of compliance with the selection of the most suitable contractor of construction work according to the principle of economic 
advantage of the offer and in terms of fulfilling the principle of $3 \mathrm{E}$ - economy, efficiency and effectiveness, taking into account the risk management of the project. This can be achieved through the purposeful use of effective hedging throughout the life cycle of construction contracts.

Elimination of risks in well-established contractual obligations and decision-making processes in the actual implementation of construction projects should lead to the efficient drawing of public funds. A functioning business environment in the construction industry is also encouraged by effective administrative support, balanced business conditions for public procurement, the selection of quality construction contractors and sharing of best practices from the implementation of investment construction in the regime of EU legislation and according to proven international contractual standards. Supporting interest in the implementation of public projects helps to provide economic stability of companies and creates space for the growth of the construction industry and the sustainable development of the public and business sector not only in the Czech Republic.

\section{Notice}

The paper will be presented at PBE2020 - International Scientific Conference "People, Buildings and Environment 2020". The $14^{\text {th }}$ conference will be held in the Rožnov pod Radhoštěm city, the Czech Republic, from 7 to 9 October 2020. The paper will not be published anywhere else.

\section{REFERENCES}

[1] Czech Statistical Office. (April 2020). Analysis of Economic Development of the Czech Republic. The Czech Republic: Ministry of Industry and Trade. Retrieved from https://www.mpo.cz/assets/cz/rozcestnik/analytickematerialy-a-statistiky/analyticke-materialy/2020/5/Analyzavyvoje-ekonomiky-CR_duben-2020.pdf

[2] Bunni, N. G. (2011). Risk and insurance in construction. London: Spon Press.

[3] Mwanaumo, E., Thwala, W., \& Mambwe, M. (2019). Multi Stakeholder Consultative Framework. Retrieved from https://www.researchgate.net/profile/Mwewa_Mambwe2/publicat ion/335501022/figure/fig1/AS:797579407269889@15671691578 34/Multi-stakeholder-consultative-framework_W640.jpg

[4] Haapio, H. \& Siedel, G. J. (2017). A Short Guide to Contract Risk. Routledge. https://doi.org/10.4324/9781315263700

[5] Prosidian Consulting. (2011). Importance of Contracts as a Risk Management Tool. Retrieved from https://www.prosidian.com/media/publications/

[6] Bloomfield, K., Williams, T., Bovis, C., \& Merali, Y. (2019). Systemic risk in major public contracts. International Journal of Forecasting, 35(2), 667-676. https://doi.org/10.1016/j.ijforecast.2018.10.005

[7] Hanak, T. (2010). Stavebni a montazni pojisteni. Stavebnictvi - Civil Engineering Journal, 2010(11-12). ISSN 1802-2030. Retrieved from http://www.casopisstavebnictvi.cz/stavebni-amontazni-pojisteni_N3914

[8] Korytarova, J. et al. (2011). Management rizik souvisejicich $s$ dodavkou stavebniho dila. Brno: CERM.

[9] Andrlova, B. \& Korytarova J. (2017). Protective Instruments for Public Works Contracts for the School Buildings. In: Organization, Technology \& Management in Construction Conference Proceedings of the $13^{\text {th }}$ International Conference,
Croatian Association for Construction Management. Zagreb: University of Zagreb. p. 231-239.

[10] Andrlova, B. \& Korytarova J. (2019). Effective hedging of business risks via protective instruments in public works contracts. In: Economic and Social Development (Book of Proceedings), $37^{\text {th }}$ International Scientific Conference on Economic and Social Development. Varazdin. p. 710-719. ISSN 1849-7535

[11] S.I.A. (2007). General Terms and Conditions for the construction completion. Retrieved from http://www.stavebnistandardy.cz/default.asp?Bid=3\&ID=3

[12] Korytárová, J., Štaffa, J., Papežíková, P., \& Špiroch, M. (2015). Financial Risk Hedging Instruments for Public Work Contracts. Organization, Technology \& Management in Construction: An International Journal, 7(3), 1352-1357. https://doi.org/10.5592/otmcj.2015.3.2

[13] Kegler Brown Hill (n.d.) (2018). Retainage Laws in the 50 States 2018. Retrieved from https://www.keglerbrown.com/ content/uploads/2018/09/Retainage-Law-in-the-50-States2018.pdf

[14] Atkinson, Andelson, Loya, Ruud \& Romo (2011). A New Law Limits Retention to 5\% on Public Works Projects. California: A Professional Law Corporation.

[15] Construction \& Engineering Law 2019: England \& Wales: ICLG. Retrieved from https://iclg.com/compare/constructionand-engineering-law

[16] NS 8407 og NS 8417. (2011). Standard Norge. Retrieved from https://www.standard.no/nyheter/nyhetsarkiv/bygg-anleggogeiendom/2013/ny-ns-8407-og-ns-8417

[17] AB 04 (2004). ABT 06 (2007). General Conditions of Contract for contracts and consulting assignments. Retrieved from https://byggtjanst.se/bokhandel/kategorier/projekteringupphan dling/upphandling-avtal-entreprenadjuridik

[18] Retention in construction contracts. (n.d.). Retrieved May 14, 2020, from

https://www.designingbuildings.co.uk/wiki/Retention_in_con struction_contracts

[19] Klee, L. (2018). International construction contract law. Hoboken: Wiley. https://doi.org/10.1002/9781119430551

[20] CEEC Research. (2019). Quarterly analysis of the Czech construction industry Q4/2019. CEEC Research. Retrieved from http://www.ceec.eu/research

[21] Global Legal Group. (n.d.) The International Comparative Legal Guides. London: Global Legal Group. Retrieved from https://iclg.com/compare/construction-and-engineering-law

[22] UK Government - Department for Business, Energy \& Industrial Strategy. (2017). Retentions in the construction industry. BEIS Research Paper, No. 2017/17. UK Government, London. Retrieved from https:/www.econstor.eu/bitstream/ 10419/196205/1/2017-17-Retention_Payments_Pye_Tait_ report.pdf

\section{Authors' contacts: \\ Barbara Andrlova, MSc \\ Brno University of Technology, \\ Faculty of Civil Engineering, \\ Veveri 331/95, 60200 Brno, Czech Republic \\ +420 774023 546, andrlova.b@gmail.com}

\author{
Jana Korytarova, Assoc. Prof. PhD (Corresponding author) \\ Brno University of Technology, \\ Faculty of Civil Engineering, \\ Veveri 331/95, 60200 Brno, Czech Republic \\ +420 733164 369, korytarova.j@fce.vutbr.cz
}

